\title{
Fiscal consolidation and unemployment: does EPL matter?: A look at EU countries
}

\author{
Alessandro Turrini
}

Correspondence:

alessandro.turrini@ec.europa.eu DG ECFIN, European Commission and IZA, Brussels, Belgium

\begin{abstract}
This paper estimates the impact of fiscal consolidation on unemployment and job market flows across EU countries using a recent database of consolidation episodes built on the basis of a "narrative" approach (Devries et al., 2011). Results show that the impact of fiscal consolidation on cyclical unemployment is temporary and significant mostly for expenditure measures. As expected, the impact of fiscal policy shocks on job separation rates is much stronger in low-EPL countries, while for high-EPL countries there is a stronger reduction in the rate at which new jobs are created. Since a reduced job-finding rate corresponds to a longer average duration of unemployment spells, fiscal policy shocks also tend to have a stronger impact on long-term unemployment if EPL for permanent contracts is stricter.
\end{abstract}

JEL codes: E62, J63, J65

Keywords: Fiscal consolidation; Unemployment; Job market flows; Employment protection legislation; Labour market reforms

\section{Introduction}

Since the outburst of the of the 2008 financial crisis, Europe is witnessing a worrying upsurge in unemployment and an unprecedented degree of dispersion of unemployment rates. The implementation of major and protracted fiscal consolidation strategies in such a context, and without prospects of a stable worldwide recovery, has stimulated debate on the growth and employment impact of consolidation measures, with implications for the coordination of timing and modalities of budgetary adjustment across EU countries (e.g., Corsetti, 2012).

Despite these concerns, a number of EU countries not only have recently put in place ambitious fiscal consolidation plans, but have also at the same time carried out major labour market reforms. In particular, the notoriously rigid and hard-to-reform Employment Protection legislation (EPL) systems of Southern European countries have been profoundly shaken with a view to stimulate job creation and tackle the problem of labour market segmentation at a juncture where severe budgetary cuts to reassure markets and put public finances on a sustainable footing where necessary.

Against this background, this paper aims at addressing a number of questions: to what extent continued fiscal consolidation across Europe would impact on unemployment? Which type of consolidation, expenditure or revenue-based, would be most employment-friendly? Does the impact of fiscal consolidation on unemployment come mostly from the job destruction side or does job creation play a relevant role as well? How do employment protection reforms interact with fiscal consolidation in 
determining unemployment and labour market flows? Are budgetary cuts more harmful when dismissals are less costly?

The analysis presented in this paper builds on various streams of existing literature. The literature on large episodes of fiscal consolidation focuses on the possible expansionary effects linked to the forward-looking behaviour of agents (e.g., Giavazzi and Pagano, 1990; Alesina et al., 2002) and on the effectiveness of these episodes in durably improving the state of public finances (e.g., Alesina and Ardagna, 1998). Another stream of literature focuses on the estimation of fiscal multipliers. Most of the empirical literature based on structural VARs identifies fiscal shocks from a-priori information on the impact of the cycle on revenues and expenditures and generally find significantly positive multipliers, but seldom larger than one (e.g., Blanchard and Perotti, 2002; Perotti, 2005).

Analyses based on a "narrative", "action-based" approach to the identification of fiscal shocks, which requires a bottom-up computation of discretionary fiscal measures reported in official documents, also estimate significantly positive multipliers, but values are often large, well above unity (e.g., Romer and Romer, 2010; Guajardo et al., 2011).

Most empirical analyses on the impact of fiscal policy focus on output, and only few papers look at the unemployment and labour market impact. Monacelli et al. (2010) develop a structural VAR for the US and estimate a negative and significant impact of government spending on unemployment and job creation, while job destruction falls. Brückner and Pappa (2012) estimate structural VARs for a number of OECD countries and show that government spending can actually raise employment and unemployment at the same time, due to the fact that it also increases participation.

The aim of this paper is to fill gaps in the existing literature in two main respects. First, it presents estimates of the impact of fiscal policy on unemployment and job market flows on EU countries: evidence is scarce for these countries. Second, it aims at shedding light on the interaction between fiscal consolidation and labour market regulation in driving labour market developments.

The baseline measure of fiscal consolidation used in the analysis is the action-based fiscal consolidation variable constructed in Devries et al. (2011), which present the double advantage of not including cyclical elements and being largely exogenous. As a countercheck, a "top-down" fiscal consolidation variable based on the cyclical adjustment of budgetary data is also used. The impact of fiscal consolidation is assessed on cyclical unemployment, on job separation and finding rates (hazard rates), and on the share of long-term unemployment. In light of limited sample size, econometric analysis spans the whole available panel of data for EU countries, but separate analysis is carried out for countries with a high vs. low degree of employment regulation.

Results confirm the finding that fiscal consolidation, notably government expenditure cuts have a significant although temporary impact on unemployment, which comes both from an increase in job destruction and a reduction in job creation. Interestingly, this unemployment impact does not differ much between high or low-EPL countries. There are considerable differences instead for what concerns job market flows, with fiscal consolidation in high-EPL countries having a much less strong impact on job destruction but also leading to a more pronounced reduction in job finding rates and, therefore, to a higher share of long-term unemployment. Such results apply to EPL for regular contracts, while countries with low EPL for temporary contracts simply exhibit 
a higher unemployment response to consolidation associated to increased job separation flows, with no significant difference for what concerns job finding rates and long-term unemployment.

The remainder of the paper is organised as follows. In the next section the data and the empirical strategy are illustrated. Section 3 presents results. The last section concludes with remarks on policy implications and suggestions for further analysis.

\section{Data and empirical strategy}

\subsection{Data}

The analysis focuses on EU countries and spans the 1980-2010 periods, although lack of data availability for some countries and variables restricts the sample.

The baseline measure of fiscal consolidation is the "action-based" variable constructed in Devries et al. (2011). Data are collected over the period 1978-2009 for 17 OECD countries, 13 of which are EU countries (Austria, Belgium, Denmark, Finland, France, Germany, Ireland, Italy, the Netherlands, Portugal, Spain, Sweden, the UK). This actionbased consolidation variable contains bottom-up estimates of the amount of measures taken by the government during years where the overall objective of fiscal policy, as reported in official statements and documents, was that of reducing the deficit and improving the state of public finances. If in a given year, in a given country, fiscal policy resulted in a reduction of the budget deficit pursued with the aim of improving public finances, the variable reports the estimated amount of discretionary measures, separately for revenues and expenditures. In all other cases, the variable is set to zero, i.e., there is no consolidation, either because the fiscal stance was expansionary or because fiscal contraction was mainly aimed at keeping under control domestic demand or at other purposes different than budgetary correction.

These "action-based" measures have a double advantage. First, they are not affected by the economic cycle, the reason being that their construction follows a bottom-up approach, i.e., the amount of measures is computed by summing up estimates contained in official documents, so that cyclical movements in the budget are kept out from the start. Second, these consolidation measures are unlikely to imply risks of reverse causation because only the fiscal adjustment episodes ex-ante driven by the objective to adjust the budget is considered.

The analysis is complemented with the use of "top-down" fiscal consolidation measures. To this purpose, data on the change in the primary structural balance, structural revenues, primary structural expenditures from the DG ECFIN AMECO database are used, which are available for all EU countries (starting from 1995 only for countries having acceded the EU in 2004 or afterwards). Budgetary data are purged from the impact of the cycle and, for years after 2002, from one-off measures. To address the issue of reverse causation, these top-down fiscal policy measures are instrumented using the variables normally used in the estimation of fiscal policy determinants by means of "fiscal reaction functions" (e.g., Bohn, 1998; Gali and Perotti, 2003).

As for unemployment, the baseline variable used is the cyclical unemployment, as obtained from the difference between the overall unemployment rate and the NAWRU (source: AMECO database). The data are available for all EU27, but only starting from 1995 for countries that acceded the EU in 2004 or after. By dealing with cyclical 
unemployment, the risk of panel non stationarity is reduced, so that the complications linked to panel co integration analysis are avoided. The underlying assumption is that, any impact of consolidation on unemployment is mostly arising from variations in cyclical unemployment.

Regarding data on job separation and job finding rates (hazard rates), the have been constructed as described in Arpaia and Curci (2010), following the methodology proposed by Shimer (2007). Data on job flows are available for all EU27 countries but for shorter time series compared with cyclical unemployment (going back to 1997 at the earliest). Data on the share of long-term unemployment on overall unemployment are taken from Euro stat and are available for all EU27 countries starting from 1992 at the earliest.

Figure 1 displays prima-facie evidence of the link between cyclical unemployment and fiscal consolidation. Figure 1a reports for each country the action-based fiscal variable and cyclical unemployment figures. It appears that cyclical unemployment was quite often relatively high during the periods where fiscal consolidations took place. Figure $1 \mathrm{~b}$ confirms this finding in a scatter plot that exhibits a positive, although weak relation between consolidation and cyclical unemployment across the panel. Of course, this prima-facie evidence does not imply causation but is suggestive of a possible link running from fiscal policy to unemployment outcomes.

\subsection{Empirical strategy}

The baseline regression framework used in the analysis of cyclical unemployment is as follows:

$$
u_{i, t}=\alpha u_{i, t-1}+\beta u_{i, t-2}+\gamma F C_{i, t}+\theta_{i}+\eta_{t}+\varepsilon_{i, t}
$$

where $i, t$ denote country and year respectively, $u_{i, t}$ is cyclical unemployment, $F C_{i, t}$ is a consolidation variable, $\theta_{t}$ and $\eta_{t}$ are, respectively, country and year fixed effects, while $\varepsilon_{i, t}$ is a standard white-noise error.

The specification amounts to an augmented AR2 model, which is motivated in light of broadly regular oscillations of cyclical unemployment around the mean (zero) over large samples.

In (1), the use of the simultaneous fiscal policy variable is justified in the case of action-based variables due to low risk of endogeneity and associated reverse causation problems.

The top-down fiscal policy variables are instead instrumented to address the endogeneity problem linked to the reaction of fiscal authorities to unemployment. The estimation in this case takes place in two stages. In the first stage, the following equation is estimated:

$$
d f_{i, t}=\alpha u_{i, t-1}+\beta u_{i, t-2}+\gamma f_{i, t-1}+\delta D_{i t-1}+\phi O G_{i t-1}+\theta_{i}+\eta_{t}+\varepsilon_{i, t}
$$

where $d f_{i, t}$ is the fiscal impulse variable (the time change in the structural primary balance as, structural revenue, or structural primary expenditure, all as a share of GDP), and among the explanatory variables, in addition to the lags of the unemployment variable, appear variables used in the estimation of standard fiscal reaction functions: the own lag of the fiscal dependent variable in levels, $f_{i, t-1}$, the lagged government / GDP ratio, $D_{i t-1}$, the lagged output gap, $O G_{i t-1}$ (the source for all instruments is the DG ECFIN AMECO database). 


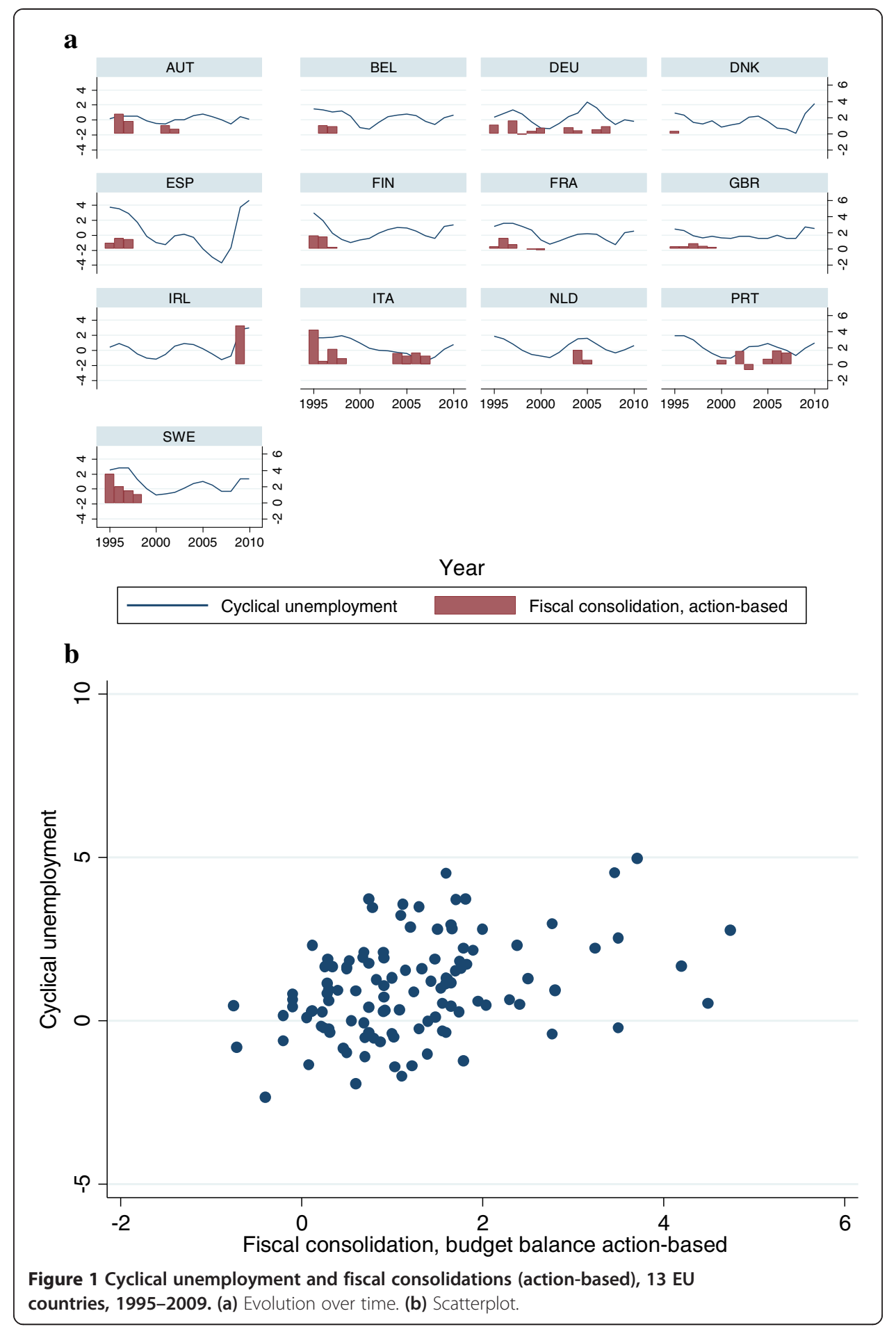

The prediction from the regression in (2) is used as the fiscal explanatory variable $\left(F C_{i, t}\right)$ in the second-stage regression, where unemployment is the dependent variable. With a view to obtain fiscal policy variables constructed in a way similar to the actionbased fiscal variables (which are set equal to zero in non-consolidation episodes), the values for $F C_{i, t}$ that do not correspond to consolidation periods are re-set to zero. A 
simple cut-off rule inspired by prudence criterion is chosen: whenever the change in the instrumented primary structural balance is less than $0.5 \%$ of GDP, the top-down fiscal policy variable $F C_{i, t}$ is re-set to zero. ${ }^{1}$

The modelling of the impact of fiscal policy on other labour market variables is analogous to (1) except that, for the case of job market flows (hazard rates) and share of long-term unemployment, the second autoregressive term is dropped (being largely insignificant).

Equation (1) is estimated by means of panel fixed effect estimation (least square dummy variables) with robust standard errors for the case of action-based consolidation measures. For top-down measures, the estimation is performed in two stages, as explained above.

With a view to shed light on the interaction between fiscal policy and labour market regulation, regressions are run separately for high and low EPL countries. The breakdown of countries is performed in the most straightforward way: countries with high (low) EPL are assumed to be those with an average value over the sample period of the OECD EPL indicator above (below) the median of such averages across the whole panel of EU27 countries. In the baseline analysis the EPL indicator used is that for permanent contracts, and a check is made also for what concerns EPL for temporary contracts.

\section{Results}

\subsection{Fiscal consolidation and unemployment}

Table 1 reports results concerning the estimated impact of fiscal policy (action-based) on cyclical unemployment. The unemployment impact multiplier of the overall budgetary consolidation variable is positive, amounting to less than $1 / 10$ of a percentage point of unemployment for each GDP point of consolidation. While the impact of government revenue is non-significant, that of government expenditure is negative, higher in absolute value and of a higher order of significance that that for the overall budget balance. The estimated unemployment impact multipliers are broadly in line with existing estimates of GDP fiscal multipliers (for instance, the estimated 0.16 coefficient for government expenditure would imply a GDP fiscal multiplier of about 0.5 assuming a standard Okun coefficient of 0.3 ).

Due to the auto-regressive process of unemployment, the peak multiplier is above the impact multiplier, as the adjustment of unemployment to the fiscal shock takes time. As shown in Figure 2, the peak effect materializes after one year (reaching almost 0.1 per cent for the overall budget and about -0.18 for expenditure cuts) and decays to zero after about 5 years. Afterwards, cyclical unemployment tends gradually to revert to pre-shock levels due to its stationarity properties.

The baseline specification in (1) using the budget balance as explanatory variable appears relatively robust. In particular, dropping the second lag of the unemployment variable (column 4) leads to a considerable change in the regression coefficient for the first lag of cyclical unemployment but the coefficient for the fiscal policy variable is not substantially affected. Robustness analysis corroborates the choice of the simultaneous rather than the lagged fiscal policy variable. Replacing the non-lagged fiscal policy variable with its own lagged value leads to a non-significant coefficient (column 5). If one lag for the fiscal policy variable is added to the baseline equation (column 6), it turns out being insignificant.

The unemployment impact of fiscal consolidation is similar if measured according to top-down variables, despite the fact that the sample used in this case comprises a larger number of countries (Table 1, columns 7, 8, 9). 
Table 1 Impact of consolidation on cyclical unemployment

\begin{tabular}{|c|c|c|c|c|c|c|c|c|c|}
\hline \multirow{4}{*}{$\begin{array}{l}\text { Dependent variable: cyclical } \\
\text { unemployment } \\
\text { Explanatory variables }\end{array}$} & (1) & (2) & (3) & (4) & (5) & (6) & (7) & (8) & (9) \\
\hline & \multicolumn{6}{|c|}{ Action-based fiscal policy variables, 13 countries EU, 1980-2009 } & \multicolumn{3}{|c|}{ “Top-down” fiscal policy variables, EU27, 1980-2010 } \\
\hline & Budget balance & Revenue & Expenditure & Budget balance & Budget balance & Budget balance & $\begin{array}{l}\text { Change in } \\
\text { structural } \\
\text { balance }\end{array}$ & $\begin{array}{l}\text { Change in } \\
\text { structural } \\
\text { revenue }\end{array}$ & $\begin{array}{l}\text { Change in structural } \\
\text { primary expenditure }\end{array}$ \\
\hline & action-based & action-based & action-based & action-based & action-based & action-based & & & \\
\hline \multirow[t]{2}{*}{ Cyclical unemployment (1 lag) } & $1.206^{* *}$ & $1.220^{* *}$ & $1.194^{* *}$ & $0.731^{* *}$ & $1.217^{* *}$ & $1.206^{* *}$ & $1.098^{* *}$ & $1.094^{* *}$ & $1.063^{* *}$ \\
\hline & {$[27.46]$} & [29.89] & {$[27.45]$} & {$[29.23]$} & {$[30.05]$} & {$[0.0441]$} & {$[19.30]$} & {$[19.74]$} & {$[15.58]$} \\
\hline \multirow[t]{2}{*}{ Cyclical unemployment (2 lags) } & $-0.609^{* *}$ & $-0.611^{* *}$ & $-0.607^{* *}$ & & $-0.614^{* *}$ & $-0.610^{* *}$ & $-0.491^{* *}$ & $-0.485^{* *}$ & $-0.458^{* *}$ \\
\hline & {$[-17.67]$} & {$[-16.80]$} & {$[-18.92]$} & & {$[-16.61]$} & {$[0.0356]$} & {$[-10.63]$} & {$[-10.52]$} & {$[-8.217]$} \\
\hline \multirow[t]{2}{*}{ Fiscal policy variable } & $0.0796+$ & 0.0184 & $-0.160^{*}$ & 0.103 & & 0.0751 & 0.142 & -0.0368 & $-0.138^{*}$ \\
\hline & {$[2.009]$} & {$[0.285]$} & {$[-2.609]$} & {$[1.595]$} & & {$[0.0465]$} & {$[1.423]$} & {$[-1.073]$} & {$[-2.738]$} \\
\hline \multirow[t]{2}{*}{ Fiscal policy variable (1 lag) } & & & & & 0.0410 & 0.0132 & & & \\
\hline & & & & & {$[1.072]$} & {$[0.0466]$} & & & \\
\hline \multirow[t]{2}{*}{ Constant } & 0.307 & $-0.236^{*}$ & 0.303 & 0.0972 & $0.340+$ & 0.308 & $-0.355^{* *}$ & $-0.289^{* *}$ & 0.221 \\
\hline & [1.682] & {$[-2.910]$} & [1.694] & {$[0.455]$} & {$[1.801]$} & [0.182] & {$[-3.294]$} & {$[-2.984]$} & [0.983] \\
\hline Observations & 353 & 353 & 353 & 366 & 353 & 353 & 546 & 547 & 548 \\
\hline R-squared & 0.864 & 0.862 & 0.865 & 0.779 & 0.862 & 0.864 & 0.748 & 0.746 & 0.740 \\
\hline Number of countries & 13 & 13 & 13 & 13 & 13 & 13 & 27 & 27 & 27 \\
\hline
\end{tabular}

$+,{ }^{*}, * *$ denote statistical significance at the $10,5,1$ per cent level respectively. $T$ tests are reported in square brackets.

Specification. All regressions include country and year fixed effects. Estimation method. Action-based fiscal policy: fixed effect panel OLS. Top-down fiscal policy measures: fixed effect panel instrumental variables (the fiscal policy variable is instrumented with its own lag, the lagged output gap, and the lagged government debt/GDP ratio). Standard errors are robust with respect to hetereoschedasticity and non-independence within country clusters.

Legend. Budget balance, action-based.(source: Devries et al., 2011): year-on-year change in government budget balance associated with fiscal consolidation measures; Revenue, action-based.: year-on-year change in government revenues associated with fiscal consolidation measures on the revenue side; Expenditure, action-based.: year-on-year change in government expenditure associated with fiscal consolidation measures on the expenditure side.

Top-down fiscal policy (source: ECFIN AMECO database). Change in structural balance = year-on-year change in cyclically-adjusted government budget balance, information on one-off measures netted out when available; Change in structural revenue = year-on-year change in cyclically-adjusted government revenues, information on one-off measures netted out when available; Change in structural expenditure = year-on-year change in cyclically-adjusted government primary expenditure, information on one-off measures netted out when available. 


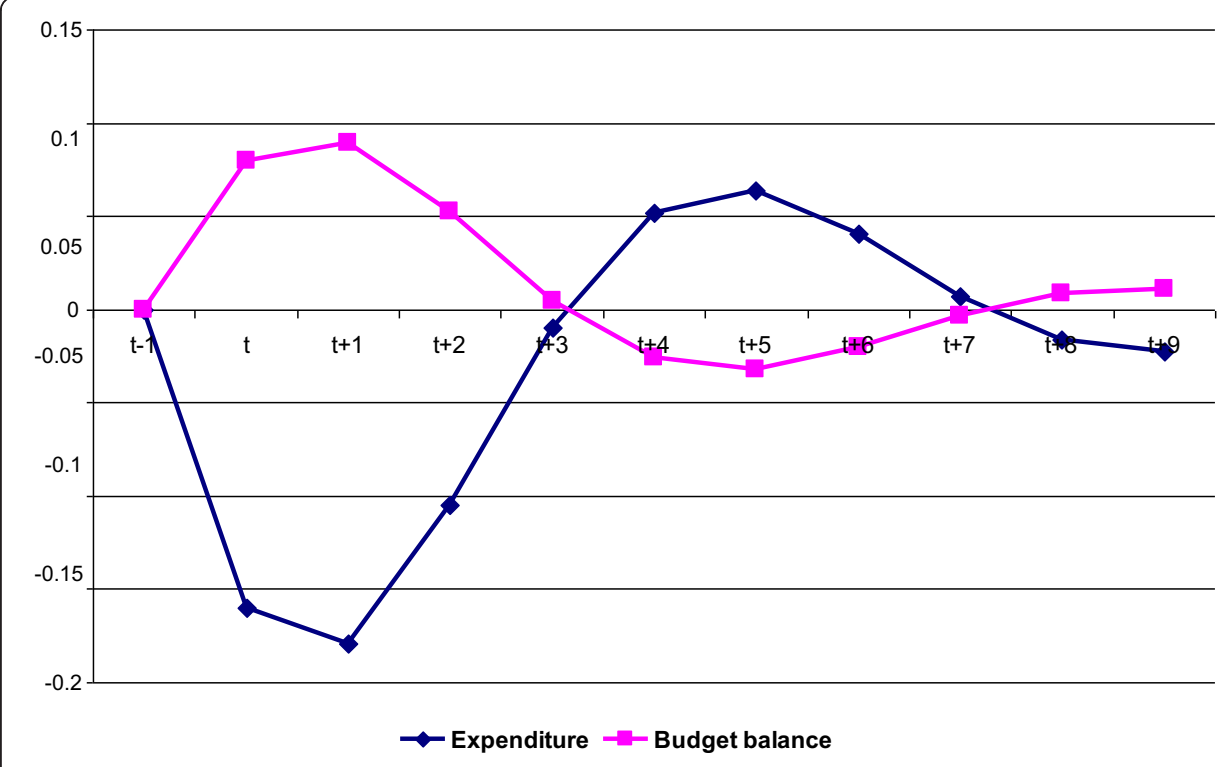

Figure 2 Fiscal consolidation impact on cyclical unemployment. Change in the unemployment rate associated with a $1 \%$ of GDP fiscal stimulus.

The impact of consolidation takes similar values also if measured on the overall unemployment rate rather than on cyclical unemployment (Table 2), with the exception of revenues, whose coefficient is in this case positive, albeit non-significant. This result reassures for what concerns the use of cyclical unemployment as baseline variable, and indicates that most of the effect of fiscal policy on unemployment falls on the cyclical component of unemployment, with relatively minor implications for the NAWRU. ${ }^{2}$

Table 2 Impact of consolidation on unemployment, action-based fiscal policy variables 13 countries EU, 1980-2009

\begin{tabular}{lccc}
\hline $\begin{array}{l}\text { Dependent variable: unemployment rate } \\
\text { Explanatory variables }\end{array}$ & $\begin{array}{c}(\mathbf{1}) \\
\text { Budget balance } \\
\text { action-based }\end{array}$ & $\begin{array}{c}\mathbf{( 3 )} \\
\text { Revenue } \\
\text { action-based }\end{array}$ & $\begin{array}{c}\mathbf{( 3 )} \\
\text { Expenditure } \\
\text { action-based }\end{array}$ \\
\hline Unemployment (1 lag) & $1.459^{* *}$ & $1.481^{* *}$ & $1.457^{* *}$ \\
{$\left[\begin{array}{l}{[22.84]} \\
{[21.55]}\end{array}\right.$} & $-0.603^{* *}$ & $-0.589^{* *}$ \\
Unemployment (2 lags) & $-0.589^{* *}$ & {$[-9.981]$} & {$[-10.65]$} \\
Fiscal policy variable & {$[-10.53]$} & 0.145 & $-0.179^{*}$ \\
& $0.129+$ & {$[1.138]$} & {$[-2.920]$} \\
Constant & {$[2.132]$} & $0.928^{* *}$ & $0.987^{* *}$ \\
Observations & $0.970^{* *}$ & {$[4.415]$} & {$[4.509]$} \\
R-squared & {$[4.624]$} & 353 & 353 \\
Number of countries & 353 & 0.927 & 0.928 \\
\hline
\end{tabular}

$+,{ }^{*}, *$ denote statistical significance at the 10,5,1 per cent level respectively. $T$ tests are reported in square brackets. Specification. All regressions include country and year fixed effects.

Estimation method. fixed effect panel OLS, standard errors robust with respect to hetereoschedasticity and nonindependence within country clusters.

Legend: for a description of the fiscal variables see notes to Table 1. 
Turning to the impact of fiscal policy on job market flows, it turns out that, in line with expectations, fiscal consolidation has a positive and significant impact on separation rates (Table 3 ). Results are also broadly in line with expectation for what concerns job finding rates (Table 4). In this case, regression coefficients do not reach significance levels but the signs of the coefficients of all variables indicate a negative impact of consolidation on job finding rates, irrespective how consolidation is measured. Moreover, $\mathrm{t}$ statistics for the budget balance variable take values between 1 and 1.5 irrespective of how it is measured,, not far from cut off values for statistical significance at 10 per cent level.

Results concerning the impact of fiscal consolidation on the share of long-term unemployment do not lend themselves to an obvious interpretation. The impact appears to be largely insignificant if action-based fiscal consolidation variables are used, negative but still insignificant if the top-down change in the structural primary balance is used (Table 5). A-priori, there is no clear expectation on the impact effect of fiscal consolidation on the share of long-term unemployment. It has been shown that a positive impact of fiscal expansion on participation rates may explain an increase in the unemployment rate rather than a reduction (Brückner and Pappa, 2012). Job flows may also play a role in driving ambiguous results of fiscal policy on unemployment. On the one hand, since fiscal policy retrenchment implies more job dismissals, the increase of unemployment inflows would lead to a reduction of the share of long-term unemployment. On the other hand, the reduction of job finding rates linked to fiscal consolidation would play in the opposite sense: longer spells into unemployment for those already jobless, and a consequent increase the long-term unemployment share. In light of these opposite effects, it is not surprising that results are non-significant or ambiguous in this case.

Table 3 Impact of consolidations on job separation rates

\begin{tabular}{|c|c|c|c|c|}
\hline \multirow{4}{*}{$\begin{array}{l}\text { Dependent variable: } \\
\text { Job separation rate }\end{array}$} & (1) & (2) & (3) & \multirow{5}{*}{$\begin{array}{l}\text { (4) } \\
\text { "Top-down" fiscal policy } \\
\text { variables, EU27, 1997-2010 } \\
\text { Change in structural balance }\end{array}$} \\
\hline & \multicolumn{3}{|c|}{$\begin{array}{l}\text { Action-based fiscal policy variables, } 13 \\
\text { EU, 1997-2009 }\end{array}$} & \\
\hline & Budget balance & Revenue & Expenditure & \\
\hline & Action-based & Action-based & Action-based & \\
\hline \multicolumn{4}{|l|}{ Explanatory variables } & \\
\hline \multirow[t]{2}{*}{ Job separation rate (1 lag) } & $0.778^{* *}$ & $0.783^{* *}$ & $0.776^{* *}$ & $0.767^{* *}$ \\
\hline & [9.692] & {$[0.0782]$} & {$[0.0806]$} & [13.18] \\
\hline \multirow[t]{2}{*}{ Fiscal policy variable } & $0.0296^{*}$ & $0.0542^{*}$ & -0.0465 & $0.0463^{*}$ \\
\hline & {$[2.518]$} & [0.0239] & {$[-0.0285]$} & {$[2.504]$} \\
\hline \multirow[t]{2}{*}{ Constant } & 0.174 & 0.172 & 0.174 & 0.131 \\
\hline & {$[1.221]$} & {$[0.141]$} & {$[0.142]$} & [1.133] \\
\hline Observations & 115 & 115 & 115 & 225 \\
\hline R-squared & 0.720 & 0.720 & 0.718 & 0.685 \\
\hline Number of countries & 13 & 13 & 13 & 27 \\
\hline \multicolumn{5}{|c|}{$\begin{array}{l}+,{ }^{*}, * \text { denote statistical significance at the } 10,5,1 \text { per cent level respectively. T tests are reported in square brackets. } \\
\text { Specification. All regressions include country and year fixed effects. } \\
\text { Estimation method. Action-based fiscal policy: fixed effect panel OLS. Top-down fiscal policy measures: fixed effect panel } \\
\text { instrumental variables (the fiscal policy variable is instrumented with its own lag, the lagged output gap, and the lagged } \\
\text { government debt/GDP ratio). Standard errors are robust with respect to hetereoschedasticity and non-independence } \\
\text { within country clusters. } \\
\text { Legend. Fiscal variables: see footnote to Table } 1 .\end{array}$} \\
\hline
\end{tabular}


Table 4 Impact of consolidations on job finding rates

\begin{tabular}{|c|c|c|c|c|}
\hline \multirow{4}{*}{$\begin{array}{l}\text { Dependent variable: } \\
\text { job finding rate } \\
\text { Explanatory variables }\end{array}$} & (1) & (2) & (3) & \multirow{4}{*}{$\begin{array}{c}\text { (4) } \\
\text { "Top-down" fiscal policy } \\
\text { variables, EU27, 1997-2010 } \\
\text { Change in structural } \\
\text { balance }\end{array}$} \\
\hline & \multicolumn{3}{|c|}{$\begin{array}{c}\text { Action-based fiscal policy variables, } 13 \\
\text { EU, 1997-2009 }\end{array}$} & \\
\hline & \multirow{2}{*}{$\begin{array}{c}\text { Budget balance } \\
\text { Action-based }\end{array}$} & \multirow{2}{*}{$\begin{array}{c}\text { Revenue } \\
\text { Action- } \\
\text { based }\end{array}$} & \multirow{2}{*}{$\begin{array}{l}\text { Expenditure } \\
\text { Action- } \\
\text { based }\end{array}$} & \\
\hline & & & & \\
\hline \multirow[t]{2}{*}{ Job finding rate (1 lag) } & $0.718^{* *}$ & $0.718^{* *}$ & $0.720^{* *}$ & $0.666^{* *}$ \\
\hline & {$[9.340]$} & {$[0.0779]$} & {$[0.0751]$} & {$[9.360]$} \\
\hline \multirow[t]{2}{*}{ Fiscal policy variable } & -0.305 & -0.516 & 0.523 & -0.259 \\
\hline & {$[-1.389]$} & {$[0.338]$} & {$[0.357]$} & {$[-1.116]$} \\
\hline \multirow[t]{2}{*}{ Constant } & $3.449^{* *}$ & $3.445^{* *}$ & $3.440^{* *}$ & $3.265^{* *}$ \\
\hline & {$[4.136]$} & {$[0.838]$} & {$[0.824]$} & {$[5.213]$} \\
\hline Observations & 115 & 115 & 115 & 229 \\
\hline R-squared & 0.594 & 0.594 & 0.593 & 0.522 \\
\hline Number of countries & 13 & 13 & 13 & 27 \\
\hline
\end{tabular}

$+,{ }^{*}, * *$ denote statistical significance at the $10,5,1$ per cent level respectively. $T$ tests are reported in square brackets. Specification. All regressions include country and year fixed effects.

Estimation method. Action-based fiscal policy: fixed effect panel OLS. Top-down fiscal policy measures: fixed effect panel instrumental variables (the fiscal policy variable is instrumented with its own lag, the lagged output gap, and the lagged government debt/GDP ratio). Standard errors are robust with respect to hetereoschedasticity and non-independence within country clusters.

Legend. Fiscal variables: see footnote to Table 1.

\subsection{The role of employment regulations}

The next step in the analysis is to estimate separately the impact of consolidation on unemployment for high and low EPL countries, with a view to assess the interplay between the unemployment effects of fiscal policy and the role of labour market regulations. Tables 6, 7, 8, 9 and 10 report results. In addition to the indicator for the EPL legislation for permanent contracts produced by the OECD, the indicator summarising

Table 5 Impact of consolidations on the share of long-term unemployment

\begin{tabular}{|c|c|c|c|c|}
\hline \multirow[b]{3}{*}{$\begin{array}{l}\text { Dependent variable: long-term } \\
\text { unemployment ratio }\end{array}$} & (1) & (2) & (3) & \multirow{3}{*}{$\begin{array}{c}\text { (4) } \\
\text { "Top-down" fiscal } \\
\text { policy variables } \\
\text { Change in structura } \\
\text { balance }\end{array}$} \\
\hline & \multicolumn{3}{|c|}{$\begin{array}{l}\text { Action-based fiscal policy variables, } \\
13 \text { EU countries, 1992-2009 }\end{array}$} & \\
\hline & Budget balance & Revenue & Expenditure & \\
\hline Explanatory variables & Action-based & Action-based & Action-based & \\
\hline \multirow[t]{2}{*}{ Long-term unemployment share (1 lag) } & $0.798^{* *}$ & $0.798^{* *}$ & $0.798^{* *}$ & $0.696^{* *}$ \\
\hline & {$[17.80]$} & {$[18.43]$} & {$[0.0451]$} & {$[16.66]$} \\
\hline \multirow[t]{2}{*}{ Fiscal policy variable } & 0.0367 & -0.000789 & -0.107 & -0.470 \\
\hline & {$[0.0668]$} & {$[-0.000893]$} & {$[-0.868]$} & {$[-0.927]$} \\
\hline \multirow[t]{2}{*}{ Constant } & $10.19^{* *}$ & $10.25^{* *}$ & $10.17^{* *}$ & $15.95^{* *}$ \\
\hline & {$[4.715]$} & {$[5.097]$} & {$[2.157]$} & [7.397] \\
\hline Observations & 206 & 206 & 206 & 371 \\
\hline R-squared & 0.855 & 0.855 & 0.855 & 0.700 \\
\hline Number of countries & 13 & 13 & 13 & 27 \\
\hline
\end{tabular}

,$+ * * *$ denote statistical significance at the $10,5,1$ per cent level respectively. $T$ tests are reported in square brackets. Specification. All regressions include country and year fixed effects.

Estimation method. Action-based fiscal policy: fixed effect panel OLS. Top-down fiscal policy measures: fixed effect panel instrumental variables (the fiscal policy variable is instrumented with its own lag, the lagged output gap, and the lagged government debt/GDP ratio). Standard errors are robust with respect to hetereoschedasticity and non-independence within country clusters.

Legend. Fiscal variables: see footnote to Table 1. 
Table 6 Impact of consolidations on cyclical unemployment by EPL strictness,

\begin{tabular}{|c|c|c|c|c|c|c|c|c|}
\hline & (1) & (2) & (3) & (4) & (5) & (6) & (7) & (8) \\
\hline \multirow{2}{*}{$\begin{array}{l}\text { Dependent variable: } \\
\text { cyclical unemployment }\end{array}$} & \multicolumn{2}{|c|}{ Budget balance } & \multicolumn{2}{|c|}{ Revenue } & \multicolumn{2}{|c|}{ Expenditure } & \multicolumn{2}{|c|}{ "Top-down” change in structural balance } \\
\hline & \multicolumn{2}{|c|}{ Action-based } & \multicolumn{2}{|c|}{ Action-based } & \multicolumn{2}{|c|}{ Action-based } & & \\
\hline \multirow[t]{2}{*}{ Explanatory variables } & \multicolumn{2}{|c|}{13 EU countries, 1980-2009 } & \multicolumn{2}{|c|}{13 EU countries, 1980-2009 } & \multicolumn{2}{|c|}{13 EU countries, 1980-2009 } & \multicolumn{2}{|c|}{21 EU countries, 1980-2010 } \\
\hline & Low EPL & High EPL & Low EPL & High EPL & Low EPL & High EPL & Low EPL & High EPL \\
\hline \multirow[t]{2}{*}{ Cyclical unemployment (1 lag) } & $1.230^{* *}$ & $1.222^{* *}$ & $1.247^{* *}$ & $1.228^{* *}$ & $1.212^{* *}$ & $1.217^{* *}$ & $1.219^{* *}$ & $1.191^{* *}$ \\
\hline & {$[27.28]$} & [12.95] & [29.48] & {$[13.26]$} & {$[25.51]$} & {$[13.45]$} & [19.49] & [22.91] \\
\hline \multirow[t]{2}{*}{ Cyclical unemployment (2 lags) } & $-0.625^{* *}$ & $-0.618^{* *}$ & $-0.630^{* *}$ & $-0.619^{* *}$ & $-0.624^{* *}$ & $-0.616^{* *}$ & $-0.599^{* *}$ & $-0.602^{* *}$ \\
\hline & {$[-16.92]$} & {$[-8.179]$} & {$[-14.33]$} & {$[-7.887]$} & {$[-19.25]$} & {$[-8.326]$} & {$[-13.30]$} & {$[-10.46]$} \\
\hline \multirow[t]{2}{*}{ Fiscal policy variable } & 0.0947 & 0.0415 & 0.0567 & -0.0103 & $-0.178+$ & -0.0891 & 0.0141 & 0.281 \\
\hline & {$[1.828]$} & {$[0.464]$} & {$[0.775]$} & {$[-0.0553]$} & {$[-2.107]$} & {$[-0.799]$} & {$[0.250]$} & {$[1.473]$} \\
\hline \multirow[t]{2}{*}{ Constant } & $0.598^{*}$ & -0.140 & $0.643^{*}$ & 0.330 & $0.584^{*}$ & -0.184 & 0.268 & -0.173 \\
\hline & {$[2.610]$} & {$[-0.834]$} & {$[2.672]$} & {$[1.510]$} & {$[2.651]$} & {$[-0.336]$} & {$[1.781]$} & {$[-1.050]$} \\
\hline Observations & 196 & 157 & 196 & 157 & 196 & 157 & 260 & 216 \\
\hline R-squared & 0.889 & 0.859 & 0.886 & 0.859 & 0.891 & 0.859 & 0.855 & 0.794 \\
\hline Number of countries & 7 & 6 & 7 & 6 & 7 & 6 & 11 & 10 \\
\hline
\end{tabular}

$t^{*},{ }^{* *}$ denote statistical significance at the 10,5, 1 per cent level respectively. $T$ tests are reported in square brackets.

Specification. All regressions include country and year fixed effects.

Estimation method. Action-based fiscal policy: fixed effect panel OLS. Top-down fiscal policy measures: fixed effect panel instrumental variables (the fiscal policy variable is instrumented with its own lag, the lagged output gap, and the lagged government debt/GDP ratio). Standard errors are robust with respect to hetereoschedasticity and non-independence within country clusters.

Legend. Fiscal variables: see footnote to Table 1. The grouping of countries with respect to the OECD EPL indicator for permanent employment is built on the basis of the median country-specific average value of the indicator over the sample period. 
Table 7 Impact of consolidations on job separation rates, distinguishing by EPL strictness

\begin{tabular}{|c|c|c|c|c|c|c|c|c|}
\hline & (1) & $(2)$ & (3) & (4) & (5) & (6) & (7) & (8) \\
\hline \multirow{2}{*}{$\begin{array}{l}\text { Dependent variable: } \\
\text { job separation rate }\end{array}$} & \multicolumn{2}{|c|}{ Budget balance } & \multicolumn{2}{|c|}{ Revenue } & \multicolumn{2}{|c|}{ Expenditure } & \multicolumn{2}{|c|}{ "Top-down" change in structural balance } \\
\hline & \multicolumn{2}{|c|}{ Action-based } & \multicolumn{2}{|c|}{ Action-based } & \multicolumn{2}{|c|}{ Action-based } & & \\
\hline \multirow[t]{2}{*}{ Explanatory variables } & \multicolumn{2}{|c|}{13 EU countries, 1997-2009 } & \multicolumn{2}{|c|}{13 EU countries, 1997-2009 } & \multicolumn{2}{|c|}{13 EU countries, 1997-2009 } & \multicolumn{2}{|c|}{21 EU countries, 1997-2009 } \\
\hline & Low EPL & High EPL & Low EPL & High EPL & Low EPL & High EPL & Low EPL & High EPL \\
\hline \multirow[t]{2}{*}{ Separation rate (1 lag) } & 0.207 & $0.795^{* *}$ & 0.233 & $0.794^{* *}$ & 0.224 & $0.790^{* *}$ & $0.608^{* *}$ & $0.782^{* *}$ \\
\hline & {$[1.293]$} & {$[14.15]$} & [1.351] & {$[15.35]$} & {$[1.395]$} & {$[11.74]$} & [4.938] & {$[17.48]$} \\
\hline \multirow[t]{2}{*}{ Fiscal policy variable } & $0.0662^{* *}$ & -0.00522 & $0.122^{* *}$ & -0.0315 & $-0.112^{* *}$ & -0.0226 & $0.0618^{* *}$ & -0.0369 \\
\hline & [5.454] & {$[-0.151]$} & [6.081] & {$[-0.573]$} & {$[-4.972]$} & {$[-0.370]$} & {$[3.635]$} & {$[-0.727]$} \\
\hline \multirow[t]{2}{*}{ Constant } & $0.588^{* *}$ & $0.156^{*}$ & $0.701^{* *}$ & $0.155^{*}$ & $0.703^{* *}$ & 0.0114 & $0.207+$ & 0.0207 \\
\hline & {$[4.401]$} & [3.654] & {$[4.737]$} & {$[3.781]$} & [5.040] & {$[0.191]$} & [2.009] & {$[0.209]$} \\
\hline Observations & 66 & 49 & 66 & 49 & 66 & 49 & 104 & 81 \\
\hline R-squared & 0.566 & 0.842 & 0.566 & 0.843 & 0.551 & 0.842 & 0.669 & 0.766 \\
\hline Number of countries & 7 & 6 & 7 & 6 & 7 & 6 & 11 & 10 \\
\hline
\end{tabular}

$+,{ }^{*}, * *$ denote statistical significance at the $10,5,1$ per cent level respectively. $T$ tests are reported in square brackets.

Specification. All regressions include country and year fixed effects.

Estimation method. Action-based fiscal policy: fixed effect panel OLS. Top-down fiscal policy measures: fixed effect panel instrumental variables (the fiscal policy variable is instrumented with its own lag, the lagged

output gap, and the lagged government debt/GDP ratio). Standard errors are robust with respect to hetereoschedasticity and non-independence within country clusters.

Legend. Fiscal variables: see footnote to Table 1. The grouping of countries with respect to the OECD EPL indicator for permanent employment is built on the basis of the median country-specific average value of the indicator over the sample period. 
Table 8 Impact of consolidations on job finding rates, distinguishing by EPL strictness

\begin{tabular}{|c|c|c|c|c|c|c|c|c|}
\hline & $(1)$ & (2) & (3) & (4) & (5) & (6) & (7) & (8) \\
\hline \multirow{2}{*}{$\begin{array}{l}\text { Dependent variable: } \\
\text { Job-finding rate }\end{array}$} & \multicolumn{2}{|c|}{ Budget balance } & \multicolumn{2}{|c|}{ Revenue } & \multicolumn{2}{|c|}{ Expenditure } & \multicolumn{2}{|c|}{ "Top-down" change in structural balance } \\
\hline & \multicolumn{2}{|c|}{ Action-based } & \multicolumn{2}{|c|}{ Action-based } & \multicolumn{2}{|c|}{ Action-based } & & \\
\hline \multirow[t]{2}{*}{ Explanatory variables } & \multicolumn{2}{|c|}{13 EU countries, 1997-2009 } & \multicolumn{2}{|c|}{13 EU countries, 1997-2009 } & \multicolumn{2}{|c|}{13 EU countries, 1997-2009 } & \multicolumn{2}{|c|}{21 EU countries, 1997-2010 } \\
\hline & Low EPL & High EPL & Low EPL & High EPL & Low EPL & High EPL & Low EPL & High EPL \\
\hline \multirow[t]{2}{*}{ Finding rate (1 lag) } & $0.845^{* *}$ & $0.678^{* *}$ & $0.844^{* *}$ & $0.672^{* *}$ & $0.848^{* *}$ & $0.685^{* *}$ & $0.822^{* *}$ & $0.610^{* *}$ \\
\hline & {$[3.872]$} & [13.09] & {$[3.894]$} & {$[10.59]$} & {$[3.881]$} & {$[12.74]$} & {$[4.587]$} & {$[9.540]$} \\
\hline \multirow[t]{2}{*}{ Fiscal policy variable } & -0.0134 & -1.192 & -0.0852 & -1.860 & -0.0417 & 1.742 & 0.122 & $-1.772^{*}$ \\
\hline & {$[-0.0668]$} & {$[-1.589]$} & {$[-0.254]$} & {$[-1.909]$} & {$[-0.104]$} & [1.221] & {$[0.876]$} & {$[-2.285]$} \\
\hline \multirow[t]{2}{*}{ Constant } & -0.283 & $3.214^{* *}$ & 2.764 & $2.948^{* *}$ & 2.738 & $3.342^{*}$ & -0.0706 & 3.422 \\
\hline & {$[-0.0898]$} & [5.319] & {$[1.262]$} & {$[6.126]$} & {$[1.243]$} & [3.958] & {$[-0.0338]$} & {$[1.366]$} \\
\hline Observations & 66 & 49 & 66 & 49 & 66 & 49 & 104 & 83 \\
\hline R-squared & 0.591 & 0.662 & 0.591 & 0.661 & 0.591 & 0.656 & 0.592 & 0.586 \\
\hline Number of countries & 7 & 6 & 7 & 6 & 7 & 6 & 11 & 10 \\
\hline
\end{tabular}

$+,{ }^{*}, * *$ denote statistical significance at the $10,5,1$ per cent level respectively. $T$ tests are reported in square brackets.

Specification. All regressions include country and year fixed effects.

Estimation method. Action-based fiscal policy: fixed effect panel OLS. Top-down fiscal policy measures: fixed effect panel instrumental variables (the fiscal policy variable is instrumented with its own lag, the lagged

output gap, and the lagged government debt/GDP ratio). Standard errors are robust with respect to hetereoschedasticity and non-independence within country clusters.

Legend. Fiscal variables: see footnote to Table 1. The grouping of countries with respect to the OECD EPL indicator for permanent employment is built on the basis of the median country-specific average value of the indicator over the sample period. 
Table 9 Impact of consolidations on the share of long-term unemployment, distinguishing by EPL strictness

\begin{tabular}{|c|c|c|c|c|c|c|c|c|}
\hline & (1) & (2) & (3) & (4) & (5) & (6) & $(7)$ & (8) \\
\hline \multirow{2}{*}{$\begin{array}{l}\text { Dependent variable: } \\
\text { long-term unemployment ratio }\end{array}$} & \multirow{2}{*}{\multicolumn{2}{|c|}{$\begin{array}{l}\text { Budget balance } \\
\text { Action-based }\end{array}$}} & \multirow{2}{*}{\multicolumn{2}{|c|}{$\begin{array}{c}\text { Revenue } \\
\text { Action-based }\end{array}$}} & \multirow{2}{*}{\multicolumn{2}{|c|}{$\begin{array}{l}\text { Expenditure } \\
\text { Action-based }\end{array}$}} & \multirow{2}{*}{\multicolumn{2}{|c|}{$\begin{array}{l}\text { "Top-down" change in } \\
\text { structural balance }\end{array}$}} \\
\hline & & & & & & & & \\
\hline \multirow[t]{2}{*}{ Explanatory variables } & \multicolumn{2}{|c|}{13 EU countries, 1992-2009 } & \multicolumn{2}{|c|}{13 EU countries, $1992-2009$} & \multicolumn{2}{|c|}{13 EU countries, $1992-2009$} & \multicolumn{2}{|c|}{21 EU countries, 1992-2010 } \\
\hline & Low EPL & High EPL & Low EPL & High EPL & Low EPL & High EPL & Low EPL & High EPL \\
\hline \multirow[t]{2}{*}{ Long-term unemployment share (1 lag) } & $0.832^{* *}$ & $0.798^{* *}$ & $0.839^{* *}$ & $0.804^{* *}$ & $0.831^{* *}$ & $0.796^{* *}$ & $0.791^{* *}$ & $0.688^{* *}$ \\
\hline & [13.05] & {$[13.71]$} & {$[16.20]$} & {$[12.77]$} & [12.69] & {$[13.45]$} & {$[19.70]$} & {$[10.42]$} \\
\hline \multirow[t]{2}{*}{ Fiscal policy variable } & -0.333 & 1.026 & -0.425 & $1.683+$ & 0.617 & -1.179 & $-0.893^{*}$ & 0.934 \\
\hline & {$[-0.587]$} & {$[1.161]$} & {$[-0.483]$} & {$[2.028]$} & {$[0.682]$} & {$[-0.708]$} & {$[-2.377]$} & {$[0.721]$} \\
\hline \multirow[t]{2}{*}{ Constant } & 3.134 & $11.08^{*}$ & $3.651^{*}$ & $10.95^{*}$ & 3.168 & $12.84^{* *}$ & $10.71^{* *}$ & $14.36^{* *}$ \\
\hline & [1.395] & [3.765] & [2.492] & [3.765] & {$[1.400]$} & [4.239] & [5.371] & [3.987] \\
\hline Observations & 116 & 90 & 116 & 90 & 116 & 90 & 168 & 143 \\
\hline R-squared & 0.901 & 0.843 & 0.901 & 0.842 & 0.901 & 0.841 & 0.831 & 0.689 \\
\hline Number of countries & 7 & 6 & 7 & 6 & 7 & 6 & 11 & 10 \\
\hline
\end{tabular}

$+,{ }^{*}, * *$ denote statistical significance at the $10,5,1$ per cent level respectively. $T$ tests are reported in square brackets.

Specification. All regressions include country and year fixed effects.

Estimation method. Action-based fiscal policy: fixed effect panel OLS. Top-down fiscal policy measures: fixed effect panel instrumental variables (the fiscal policy variable is instrumented with its own lag, the lagged

output gap, and the lagged government debt/GDP ratio). Standard errors are robust with respect to hetereoschedasticity and non-independence within country clusters.

Legend. Fiscal variables: see footnote to Table 1. The grouping of countries with respect to the OECD overall EPL indicator for permanent employment is built on the basis of the median country-specific average value

of the indicator over the sample period. 
Table 10 Impact of consolidations, distinguishing by EPL strictness for temporary employment

\begin{tabular}{|c|c|c|c|c|c|c|c|c|}
\hline \multirow{3}{*}{$\begin{array}{l}\text { Dependent variables } \\
\text { Explanatory variables }\end{array}$} & (1) & (2) & (3) & (4) & (5) & (6) & (7) & (8) \\
\hline & \multicolumn{2}{|c|}{ Cyclical unemployment } & \multicolumn{2}{|c|}{ Job separation rates } & \multicolumn{2}{|c|}{ Job finding rates } & \multicolumn{2}{|c|}{$\begin{array}{c}\text { Share of long-term } \\
\text { unemployment }\end{array}$} \\
\hline & Low EPL & High EPL & Low EPL & High EPL & Low EPL & High EPL & Low EPL & High EPL \\
\hline \multirow[t]{2}{*}{ Dependent variable (1 lag) } & $1.116^{* *}$ & $1.298^{* *}$ & $0.667^{* *}$ & $0.860^{* *}$ & $0.784^{* *}$ & $0.704^{* *}$ & $0.687^{* *}$ & $0.848^{* *}$ \\
\hline & [24.38] & {$[15.71]$} & [6.919] & {$[17.26]$} & {$[5.706]$} & [14.80] & {$[6.440]$} & {$[14.65]$} \\
\hline \multirow[t]{2}{*}{ Dependent variable (2 lags) } & $-0.573^{* *}$ & $-0.673^{* *}$ & & & & & & \\
\hline & {$[-11.86]$} & {$[-8.563]$} & & & & & & \\
\hline \multirow[t]{2}{*}{ Budget balance Action-based } & $0.135^{*}$ & $0.110+$ & $0.0412^{*}$ & -0.0167 & 0.0209 & -0.888 & 0.509 & -0.497 \\
\hline & {$[3.594]$} & {$[2.395]$} & {$[2.892]$} & {$[-0.327]$} & {$[0.0519]$} & {$[-0.864]$} & {$[0.769]$} & {$[-1.017]$} \\
\hline \multirow[t]{2}{*}{ Constant } & $0.603^{*}$ & $-0.223^{* *}$ & $0.523^{* *}$ & -0.231 & $4.969^{* *}$ & 2.734 & 4.256 & $7.252+$ \\
\hline & {$[2.735]$} & {$[-4.057]$} & [7.633] & {$[-0.727]$} & {$[4.330]$} & {$[1.042]$} & [1.451] & {$[2.255]$} \\
\hline Observations & 196 & 157 & 60 & 55 & 60 & 55 & 104 & 102 \\
\hline R-squared & 0.885 & 0.885 & 0.699 & 0.785 & 0.641 & 0.631 & 0.887 & 0.850 \\
\hline Number of countries & 7 & 6 & 7 & 6 & 7 & 6 & 7 & 6 \\
\hline
\end{tabular}

Action-based budget balance.

13 EU countries, 1992-2009.

$+,{ }^{*}, * *$ denote statistical significance at the 10, 5, 1 per cent level respectively. $T$ tests are reported in square brackets.

Specification. All regressions include country and year fixed effects.

Estimation method: fixed effect panel OLS, standard errors robust with respect to hetereoschedasticity and non-independence within country clusters.

Legend. Fiscal variables: see footnote to Table 1. The grouping of countries with respect to the OECD EPL indicator for temporary employment is built on the basis of the median country-specific average value of the indicator for years after 2005. 
only the legislation for the use and termination of temporary labour contracts is also considered. Countries are split according the median of the country-specific average of the EPL indicators over the sample.

Table 6 reports results for the impact on cyclical unemployment. When running the analysis separately for high-EPL and low-EPL countries, it is found that fiscal consolidations have a somehow larger effect in unregulated labour markets, even though, most probably in light of the reduction in sample size, the estimated fiscal policy effect is not anymore significant when the sample is split according to EPL. Using the top-down change in the structural primary balance as a fiscal consolidation variable, it also appears that fiscal consolidation has no statistically significant impact on cyclical unemployment, with a higher coefficient in high-EPL countries.

The result that fiscal consolidation has no very different effects in more and less regulated labour markets runs against the intuition. The explanation could lie in the different behaviour of job creation and job destruction. It is well-known from existing theory and evidence that strict EPL is associated with lower exit rates from unemployment but also with a lower probability for the unemployed to find a new job (Mortensen and Pissarides, 1994; Gomez-Salvador et al., 2004). It could be the case that in high-EPL countries fiscal policy shocks destroy less jobs but also lead to a stronger reduction in the rate at which new jobs are created, with a possibly overall strong effect on cyclical unemployment.

The estimation of the impact of fiscal consolidation on job market flows separately for high and low-EPL countries supports the above hypothesis. As shown in Table 7, job separation rates rise significantly with fiscal retrenchments only in low-EPL countries. Discretionary changes in the overall budget balance, government revenue, government expenditure are all insignificant in high-EPL countries while they are largely significant and with the expected sign in low-EPL countries. Conversely, job finding rates appear to react negatively to fiscal consolidation mostly in high-EPL countries (Table 8).

The fact that job market flows react differently to fiscal consolidation according to the EPL regime helps disentangling the impact of fiscal retrenchment on the share of longterm unemployment. Since a reduced job finding rate corresponds to a longer average duration of unemployment spells, one would expect that fiscal policy shocks also tend to raise the share of long-term unemployment in high-EPL countries. The evidence reported in Table 9 supports this expectation: fiscal consolidation is more likely to raise the longterm unemployment ratio in countries with stricter EPL regimes.

Results in Tables 6, 7, 8, 9 make use of a sample split of countries according to the OECD indicator for the EPL legislation for permanent contracts. It is well-known that, across EU countries, significant differences are found concerning the way in which temporary labour contracts are regulated, with some countries being characterised by a "dual" EPL regime, with relatively flexible conditions for the use and termination of temporary contracts coupled with heavy regulations on dismissals for permanent contracts. With a view to check whether EPL for temporary contracts also matter for the labour market impact of fiscal consolidation, Table 10 reports results splitting countries according to the OECD EPL indicator for temporary employment.

The fiscal consolidation variable is the action-based fiscal measures affecting the whole budget balance, and results are reported for cyclical unemployment, job market flows, and the share of long-term unemployment. As compared with the sample split 
operated on the basis of the EPL index for permanent employment, the evidence is quite different. As the intuition would suggest, the stronger unemployment reaction in low-EPL countries is associated with larger job separation flows. As for job finding rates, they appear to be more strongly reduced during consolidations in countries with higher EPL, but in this case the impact is not statistically significant. This may contribute to explain why consolidation appears not to have a stronger impact on the long-term unemployment ratio in high-EPL countries, as opposed to what found when splitting the sample according to EPL for permanent contracts.

\section{Conclusions}

Overall, the evidence confirms that fiscal consolidation has an impact on cyclical unemployment in the order of $0.1 \%$ of additional unemployment for each point of GDP of budgetary measures, stronger for expenditure measures, and which gradually fades away.

Results also show that while fiscal consolidation may not necessarily lead to higher overall unemployment in countries with more regulated labour markets, there are reasons to expect that in those countries the impact on unemployment composition could be more worrying, being stricter EPL associated with a stronger reduction in job creation and a higher incidence of long-term unemployment. In this respect, the findings bode well for the strategy recently followed by some EU countries and support the view that in the current juncture tackling the challenges facing the euro area requires a multi-pillar approach comprising both fiscal consolidation and courageous structural reforms (Buti and Padoan, 2012). The findings also suggest that reform approaches aimed at reducing "dual" EPL systems during consolidation would not necessarily be harmful, as it appears that it is mostly EPL for regular employment that matters for the impact of fiscal cuts on job finding rates.

The findings in this paper have also implications for the feasibility of structural reforms during austerity periods. Although it is well-known that certain labour market reforms may be hard to square with fiscal consolidation because of their electoral (e.g., Buti et al., 2010) or budgetary costs (e.g., Deroose and Turrini, 2005), governments with a strong mandate to bring public finances on a sustainable footing while taking courageous measures to improve to capacity of the economy to create jobs may be able to carry out austerity measures and reform employment protection at the same time.

Further analysis on this topic seems deserved, not only to further check robustness of results with respect to the measurement of fiscal policy, the specification of empirical equations, and the definition of the sample, but also to better qualify results in terms of which EPL policy settings matter most in driving results.

\section{Endnotes}

${ }^{1}$ The 0.5 per cent cut-off value for the instrumented change in the structural balance nets out minor consolidation episodes and permits to isolate a roughly equal number of consolidation episodes as those identified with the action-based approach over the sample period for the $13 \mathrm{EU}$ countries for which data are available for both measures (120 actionbased consolidation period, 117 top-down consolidation periods). The action-based and the top-down consolidation measures also exhibit a roughly similar average (respectively, 
1.2 per cent of GDP and 0.8 per cent of GDP, respectively) and a fairly high (0.38), statistically significantly rank correlation.

${ }^{2}$ These conclusions are however to be taken with caution in light of the risk of inconsistent estimates in Table 3 arising from the likely non-statioarity of the unemployment rate, revealed inter-alia by the high first-order auto-regressive coefficient.

\section{Competing interests}

The IZA Journal of Labor Policy is committed to the IZA Guiding Principles of Research Integrity. The author declares that he has observed these principles.

\section{Acknowledgements}

I would like to thank David Leigh for guidance on the data and Alfonso Arpaia, Marco Buti and Lucio Pench for helpful discussions and suggestions. An anonymous referee and an editor of this journal contributed to improve the final version of the paper.

\section{Disclaimer}

The views expressed in this paper are those of the author and do not correspond necessarily with those of the European Commission.

Responsible Editor: Juan Francisco Jimeno.

Received: 25 March 2013 Accepted: 18 June 2013

Published: 8 July 2013

\section{References}

Alesina A, Ardagna S (1998) Tales of fiscal adjustment. Economic Policy 27:489-45

Alesina A, Ardagna S, Perotti R, Schiantarelli F (2002) Fiscal policy, profits, and investment. American economic review 92:571-89 Arpaia A, Curci N (2010) EU labour market behavious during the great recession. European Economy Economic Papers no. 405 Blanchard O, Perotti R (2002) An empirical characterization of the dynamic effects of changes in government spending and taxes on output. Quarterly Journal of Economics 117:1329-68

Bohn H (1998) The behaviour of US public debt and deficits. Quarterly Journal of Economics 113:949-63

Brückner M, Pappa E (2012) Fiscal expansions, unemployment, and labour force participation: theory and evidence. International Economic Review 53:1205-28

Buti M, Padoan PC (2012) From vicious to virtuous: A five-point plan for euro-zone restoration. CEPR Policy Insight No. 61 Buti M, Turrini A, Van den Noord P, Biroli P (2010) Reforms and re-elections in OECD countries. Economic Policy 25:61-116

Corsetti G (2012) Has austerity gone too far?., Vox.org, 2 April

Deroose S, Turrini A (2005) The short-term budgetary implications of structural reforms: evidence from a panel of EU countries. CEPR Discussion Paper No. 5217

Devries P, Guajardo J, Leigh D, Pescatori A (2011) A new action-based dataset of fiscal consolidation. IMF Working Paper, WP/11/128

Gali J, Perotti R (2003) Fiscal policy and monetary integration in Europe. Economic Policy 18(37):533-572

Giavazzi F, Pagano M (1990) "Can severe fiscal contractions be expansionary? Tales of two small European countries,". In: NBER Chapters in: NBER Macroeconomics Annual 1990, Volume 5. National Bureau of Economic Research, Inc, pp 75-122

Gomez-Salvador R, Messina J, Vallanti G (2004) Gross job flows and institutions in Europe. Labour Economics 11:469-485 Guajardo J, Leigh D, Pescatori A (2011) Expansionary austerity: New international evidence. IMF Working Paper, WP/11/158 Monacelli T, Perotti R, Trigari A (2010) Unemployment fiscal multipliers. Journal of Monetary Economics 97(5):531-553 Mortensen D, Pissarides C (1994) Job creation and job destruction in the theory of unemployment. The Review of Economic Studies 61(3):397-415

Perotti R (2005) Estimating the effects of fiscal policy in OECD countries. Proceedings, Federal Reserve Bank of San Francisco Romer CD, Romer DH (2010) The macroeconomic effects of Tax changes: estimates based on a new measure of fiscal shocks. American Economic Review 100(3):763-801

Shimer D (2007) Reassessing the ins and outs of unemployment. NBER Working Paper No. 13421

doi:10.1186/2193-9004-2-8

Cite this article as: Turrini: Fiscal consolidation and unemployment: does EPL matter?: A look at EU countries. IZA Journal of Labor Policy 2013 2:8. 